\title{
Characterization of an L-arabinose isomerase from Bacillus coagulans NL01 and its application for D-tagatose production
}

\author{
Wending Mei $^{1}$, Lu Wang ${ }^{1}$, Ying Zang ${ }^{2}$, Zhaojuan Zheng ${ }^{1}$ and Jia Ouyang ${ }^{1,3^{*}}$
}

\begin{abstract}
Background: L-arabinose isomerase (Al) is a crucial catalyst for the biotransformation of D-galactose to D-tagatose. In previous reports, Als from thermophilic bacterial strains had been wildly researched, but the browning reaction and by-products formed at high temperatures restricted their applications. By contrast, Als from mesophilic Bacillus strains have some different features including lower optimal temperatures and lower requirements of metallic cofactors. These characters will be beneficial to the development of a more energy-efficient and safer production process. However, the relevant data about the kinetics and reaction properties of Bacillus Als in D-tagatose production are still insufficient. Thus, in order to support further applications of these Als, a comprehensive characterization of a Bacillus Al is needed.

Results: The coding gene (1422 bp) of Bacillus coagulans NL01 Al (BCAl) was cloned and overexpressed in the Escherichia coli BL21 (DE3) strain. The enzymatic property test showed that the optimal temperature and pH of BCAI were $60{ }^{\circ} \mathrm{C}$ and 7.5 respectively. The raw purified BCAl originally showed high activity in absence of outsourcing metallic ions and its thermostability did not change in a low concentration $(0.5 \mathrm{mM})$ of $\mathrm{Mn}^{2+}$ at temperatures from $70{ }^{\circ} \mathrm{C}$ to $90^{\circ} \mathrm{C}$. Besides these, the catalytic efficiencies $\left(k_{\text {cat }} / K_{\mathrm{m}}\right)$ for L-arabinose and D-galactose were $8.7 \mathrm{mM}^{-1} \mathrm{~min}^{-1}$ and $1.0 \mathrm{mM}^{-1} \mathrm{~min}^{-1}$ respectively. Under optimal conditions, the recombinant $E$. coli cell containing BCAl could convert $150 \mathrm{~g} \mathrm{~L}^{-1}$ and $250 \mathrm{~g} \mathrm{~L}^{-1}$ D-galactose to D-tagatose with attractive conversion rates of $32 \%(32 \mathrm{~h})$ and $27 \%(48 \mathrm{~h})$.

Conclusions: In this study, a novel Al from B. coagulans NL01 was cloned, purified and characterized. Compared with other reported Als, this Al could retain high proportions of activity at a broader range of temperatures and was less dependent on metallic cofactors such as $\mathrm{Mn}^{2+}$. Its substrate specificity was understood deeply by carrying out molecular modelling and docking studies. When the recombinant E. coli expressing the Al was used as a biocatalyst, D-tagatose could be produced efficiently in a simple one-pot biotransformation system.
\end{abstract}

Keywords: L-arabinose isomerase, Bacillus coagulans, D-tagatose, Biotransformation

\footnotetext{
*Correspondence: hgouyj@nifu.edu.cn

${ }^{1}$ College of Chemical Engineering, Nanjing Forestry University, Nanjing

210037, People's Republic of China

${ }^{3}$ Key Laboratory of Forest Genetics \& Biotechnology of the Ministry of

Education, Nanjing, People's Republic of China

Full list of author information is available at the end of the article
} 


\section{Background}

D-tagatose is a natural rare ketohexose that possesses $92 \%$ of the sweetness, but only $38 \%$ of the calories of sucrose [1]. Since it attained GRAS (Generally Recognized As Safe) status under U.S. Food and Drug Administration (FDA) regulations, D-tagatose has become a promising functional sweetener on the food market. Until now, it has been used in the productions of confectionery, soft drinks and health foods for improving the flavors and reducing the calories. It also shows positive attributes in treatment of type II diabetes and hyperglycemia. Currently, one mature method for D-tagatose production is the direct isomerization of $\mathrm{D}$-galactose into D-tagatose with metal hydroxides as the chemical catalysts under basic conditions [2]. This process was applied into commercial food grade D-tagatose production by Arla Food Company between 2002 and 2006 [3]. Nevertheless, it has been gradually dismissed because of the drastic reaction conditions and high cost of the subsequent purification steps. Another method is the enzymatic process that mainly depends on L-arabinose isomerase (AI, EC 5.3.1.4). AIs can isomerize Dgalactose to D-tagatose in one step at a milder environment. The method has some significant advantages over the chemical process, such as a lower alkali dosage and less unexpected by-products [3].

In microorganisms, AIs are encoded by the $\operatorname{ara} A$ genes which is an important component of the L-arabinose operon and responsible for the conversion of $\mathrm{L}$-arabinose to L-ribulose [4]. AIs can also recognize D-galactose and catalyze it to D-tagatose due to the similar molecular conformations of D-galactose and L-arabinose (Fig. 1). But many studies showed that the catalytic efficiency $\left(k_{\text {cat }} / K_{\mathrm{m}}\right)$ of AIs for L-arabinose was generally 10 times (or higher) than that for D-galactose and some AIs even did not show any catalytic efficiency for D-galactose [5]. Since the AI from Lactobacillus gayonii was presumed to be a catalyst for D-galactose isomerization in 1993 [6], about 40 types of microbial AIs have been identified and characterized so far. A large proportion of them achieved the maximal enzyme activities under moderate high temperatures $\left(50{ }^{\circ} \mathrm{C}\right.$ to $\left.80{ }^{\circ} \mathrm{C}\right)$ and neutral-alkaline conditions ( $\mathrm{pH} 7.0$ to 8.0). In addition, most studies on AIs were dependent on metallic ions. $\mathrm{Mn}^{2+}$ and $\mathrm{Co}^{2+}$ always served as the activating factors of AIs and can significantly improve the enzyme activities and thermal stabilities [7]. Metallic ions in reaction mixtures are difficult to be removed in industry. Thus, their presence will reduce the purity and safety of target products.

Several reports indicated that high reaction temperature is a favorable condition for D-tagatose formation $[8,9]$. Numerous AIs from thermophile strains have been reported since the year 2000 including Thermotoga maritima, Thermotoga neapolitan, Anoxybacillus flavithermus, Bacillus stearothermophilus US100 [8-11]. Their optimal temperatures were within 80 to $95{ }^{\circ} \mathrm{C}$. High operation temperature causes browning reaction and formation of by-products in catalysis, which is a big obstacle for isolation of the target product [5]. Therefore, many researchers changed their interests to AIs from mesophilic Bacillus strains such as Bacillus licheniformis, Bacillus subtilis, Bacillus halodurans and Bacillus coagulans [12-15]. These enzymes could adapt to moderate temperatures from $50{ }^{\circ} \mathrm{C}$ to $60{ }^{\circ} \mathrm{C}$. They possessed inherently high $k_{\text {cat }} / K_{\mathrm{m}}$ values for the natural substrate L-arabinose. Therefore, their applications mainly focused on the synthesis of L-ribulose. Only $B$. halodurans AI was reported to show a $k_{\text {cat }} / K_{\mathrm{m}}$ of $0.4 \mathrm{mM}^{-1} \mathrm{~min}^{-1}$ toward
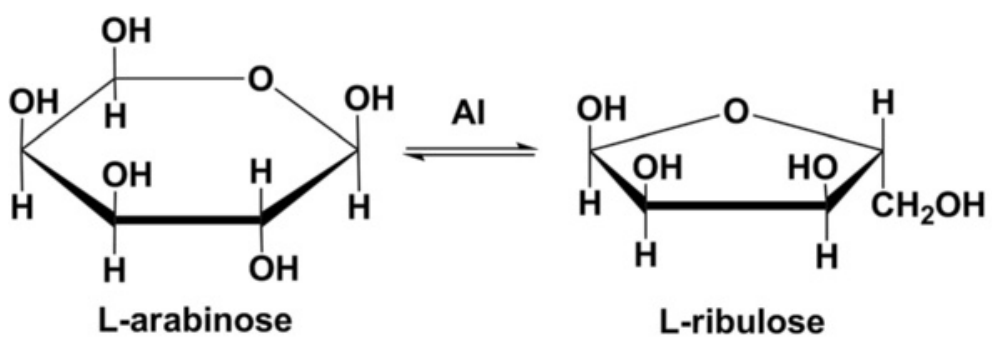

L-ribulose
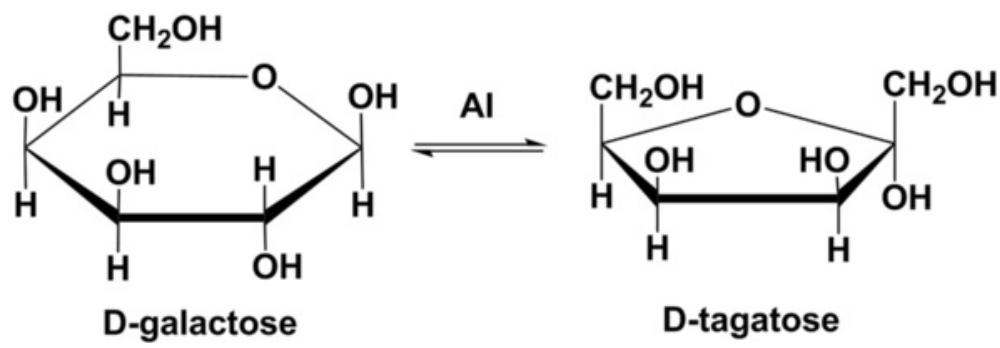

Fig. 1 Isomerization of L-arabinose to L-ribulose and isomerization of D-galactose to D-tagatose catalyzed by Al 
D-galactose. Relevant data about the properties of Bacillus AIs in D-tagatose production are insufficient and needed to be complemented.

In this study, an ara $A$ gene from the $B$. coagulans NL01 was cloned and expressed in Escherichia coli BL21 (DE3). The biochemical properties of purified B. coagulans AI (BCAI) were comprehensively studied. Whole cells of $E$. coli expressing BCAI were used to produce Dtagatose under high D-galactose concentrations in order to test its actual bioconversion capacity.

\section{Results and discussion}

\section{Over-expression and purification of BCAI}

The $\operatorname{ara} A$ gene contained an open reading frame (ORF) of 1422 base pairs encoding a protein of 473 amino acids. Protein sequence alignments showed that, among the AIs with high activities toward D-galactose, BCAI was mostly similar to Lactobacillus sakei AI and Pediococcus pentosaceus AI with identities of 68.8 and $67.5 \%$ respectively. By contrast, the identities to other AIs without obvious D-galactose activities from Bacillus strains including B. halodurans (57.1\%) and B. substilis (55.6 \%) were lower (Fig. 2). Expression was induced upon addition of IPTG in Luria Bertani (LB) medium. The activity of BCAI crude extract was $2.3 \mathrm{U} \mathrm{mg}^{-1}$ for $\mathrm{L}$-arabinose and $0.3 \mathrm{U} \mathrm{mg}^{-1}$ for D-galactose. Then, the crude extract was subjected to heat treatment $\left(60{ }^{\circ} \mathrm{C}\right)$ and purified by HisTrap HP $5 \mathrm{~mL}$ column. SDS-PAGE showed distinct bands with a molecular mass around $55 \mathrm{kDa}$ (expected size: $53.5 \mathrm{kDa}$, Additional file 1: Figure S1). The electrophoretically pure AI showed a specific activity of $8.0 \mathrm{U} \mathrm{mg}^{-1}$ toward L-arabinose (Table 1) and $1.1 \mathrm{U} \mathrm{mg}^{-1}$ toward D-galactose. BCAI was highly similar to the AI from $B$. coagulans 2-6 with an identity of $96.0 \%$, but no reports indicated that B. coagulans 2-6 AI possessed the same D-galactose activity [14].

\section{Effects of temperature and $\mathrm{pH}$ on activity of BCAI}

The effects of temperature were determined at 40 to $90{ }^{\circ} \mathrm{C}$ and $\mathrm{pH} 7.5$ (Fig. 3a). BCAI displayed its maximal activity at $60{ }^{\circ} \mathrm{C}$ and retained above $85 \%$ of the activity at 50 to $70{ }^{\circ} \mathrm{C}$. Even at 80 to $90{ }^{\circ} \mathrm{C}$, it still preserved above $60 \%$ of the maximal activity. Compared with the AIs from $B$. stearothermophilus IAM11001, Lactobacillus fermentum CGMCC2921 and T. mathranii, BCAI was less sensitive to temperature change and could adapt to a broader range of temperatures $[16,17]$.

To investigate the effect of $\mathrm{pH}$, enzyme assays were carried out at a series of $\mathrm{pH}$ from 2.2 to 9.0. The relative activity of BCAI reached the maximal value at $\mathrm{pH} 7.5$ (Fig. 3b) and decreased by less than $10 \%$ at $\mathrm{pH} 8.0$ to 9.0 . By contrast, the activity was weaker at acidic conditions. It decreased severely when the $\mathrm{pH}$ dropped to 5.0 as most of moderate alkaline AIs did previously, possibly because some side chain groups close to its substrate binding sites were difficult to ionize under this condition [18].

It has been experimentally proved that the optimum $\mathrm{pH}\left(\mathrm{pH}_{\mathrm{opt}}\right)$ of AIs is affected by some crucial residues with polar groups, for example the E268 residue of $B$. halodurans AI (BHAI, $\mathrm{pH}_{\mathrm{opt}}=8.0$ ) and the equivalent D269 of L. fermentum AI (LFAI, $\mathrm{pH}_{\mathrm{opt}}=6.5$ ) [13, 17]. Modifications of the two residues to lysine (K) resulted that the $\mathrm{pH}_{\mathrm{opt}}$ of BHAI and LFAI decreased to 7.0 and 5.0, respectively $[19,20]$. Protein sequence alignment showed D268 in BCAI was the counterpart of E268 of BHAI and D269 of LFAI (Fig. 2a). It could be presumed that if the D268 residue was changed to lysine, the $\mathrm{pH}_{\mathrm{opt}}$ of BCAI would probably decrease to a lower value.

\section{Effects of metallic ions on activity and thermostability of BCAI}

After BCAI was treated by ethylenediamine tetraacetic acid (EDTA), a dramatic loss (60\%) of activity was observed in an enzyme assay at $60{ }^{\circ} \mathrm{C}$ and $\mathrm{pH}$ 7.5. The EDTA-treated enzyme was then incubated in Tris- $\mathrm{HCl}$ ( $\mathrm{pH}$ 7.5) solutions with different types of divalent metallic ions $\left(\mathrm{Mg}^{2+}, \mathrm{Ca}^{2+}, \mathrm{Mn}^{2+}, \mathrm{Fe}^{2+}, \mathrm{Co}^{2+}, \mathrm{Ni}^{2+}, \mathrm{Cu}^{2+}\right)$. Enzyme assays showed that, except $\mathrm{Cu}^{2+}$, all other divalent ions could serve as activators (Fig. 4a). $0.5 \mathrm{mM} \mathrm{Mn}^{2+}$ and $0.5 \mathrm{mM} \mathrm{Co}^{2+}$ respectively boosted the activity by 270 and $190 \%$ and the combination of them finally resulted in a $370 \%$ increase. Previous researches had demonstrated that $\mathrm{Mn}^{2+}$ or $\mathrm{Co}^{2+}$ could assist AIs to transfer to correct substrate-binding conformations at elevated temperatures [21]. They significantly boosted the activities of AIs from other strains such as T. maritima, L. fermentum CGMCC2921 and G. thermodenitrificans $[9,17,22]$, but some of them required higher $\mathrm{Mn}^{2+}$ or $\mathrm{Co}^{2+}$ concentrations $(\geq 2 \mathrm{mM})$. In this study, when the $\mathrm{Mn}^{2+}$ concentration was increased from $0.5 \mathrm{mM}$ to $4 \mathrm{mM}$, the BCAI activity changed very slightly (Fig. $4 \mathrm{~b}$ ). $0.5 \mathrm{mM} \mathrm{Mn}{ }^{2+}$ was completely sufficient for BCAI to maintain a high activity. Further increase of $\mathrm{Mn}^{2+}$ by many times could not boost BCAI activity effectively but also would influence the quality of products. For purified BCAI without EDTA treatment, which will be called raw purified BCAI below, the activity was 92.6 and $72.5 \%$, i.e. very close to the activity of EDTA-treated enzyme measured in $0.5 \mathrm{mM} \mathrm{Co}^{2+}$ and $\mathrm{Mn}^{2+}$ solutions (Fig. 4a), possibly because it originally bonded metal ions or other types of ligands in the E. coli cells.

As EDTA treatment would not be used in practical applications of AIs, the thermal stability test was carried out using the raw purified BCAI. Figure 5a showed it was perfectly stable at $60{ }^{\circ} \mathrm{C}$. After an incubation of $2 \mathrm{~h}$ at this temperature, it preserved $90 \%$ of the initial 


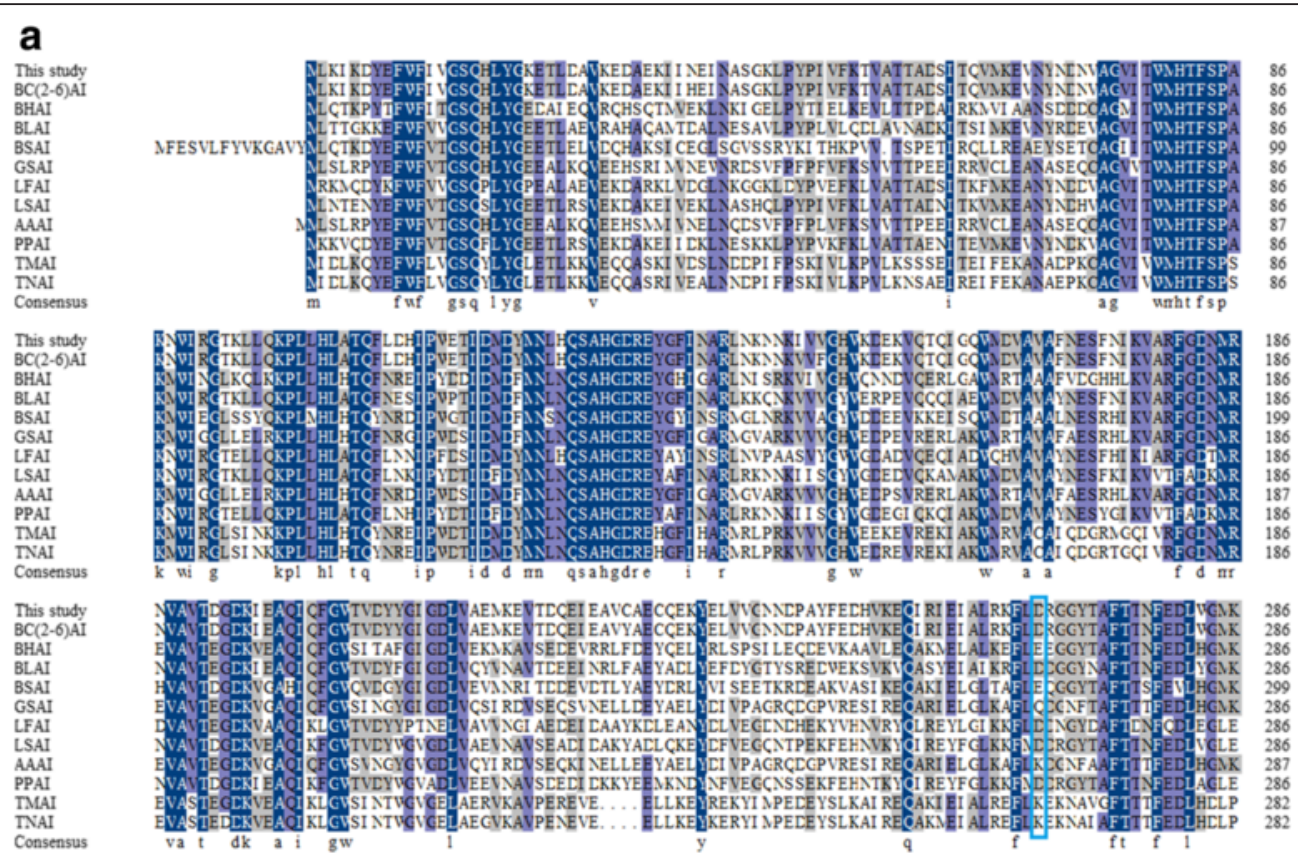

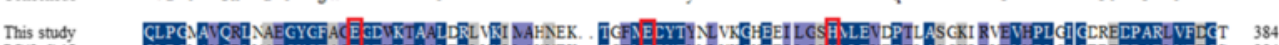

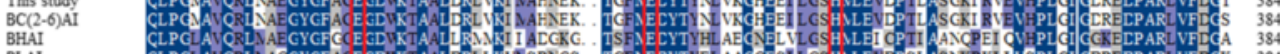
BSAI GSAI LFA PAAI

TMAI Consensus

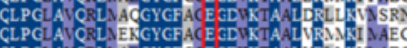

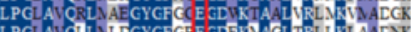
作

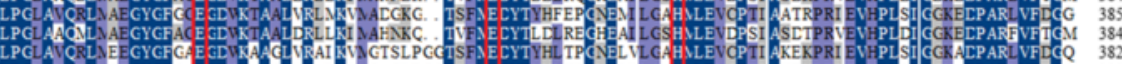

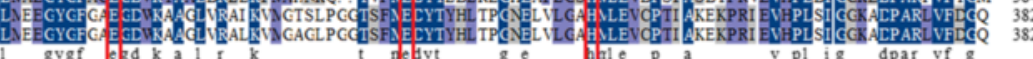

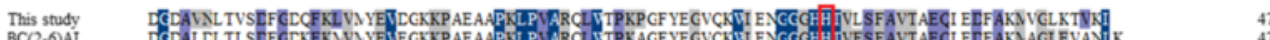
BC(2-2) BHAI

BLAA

GSAI

LFA
LSAI

AAAI

PPAI

Consensus

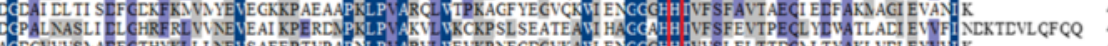

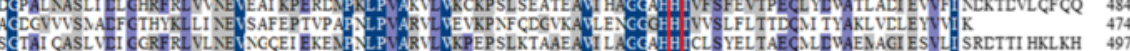

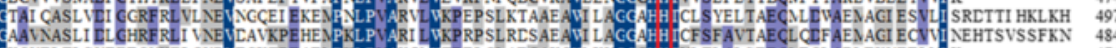

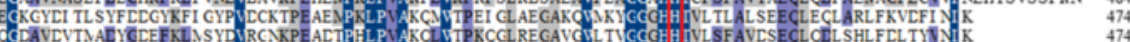

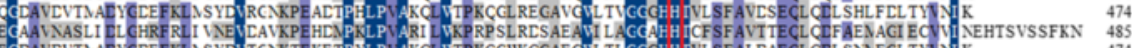

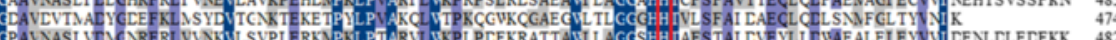

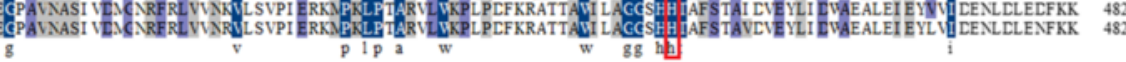

This study
$B C(2-6)$ AI

BHAI

BLAI

GSAA

LFAI

AAAI ELRVNEVFURCR

EIKVNEALYRLCK

$\begin{array}{ll}\text { PPAA } & \text { ELRVNELYWCLLK } \\ \text { TMAI } & \text { ELRVNELYWGLLK }\end{array}$

b

0.05

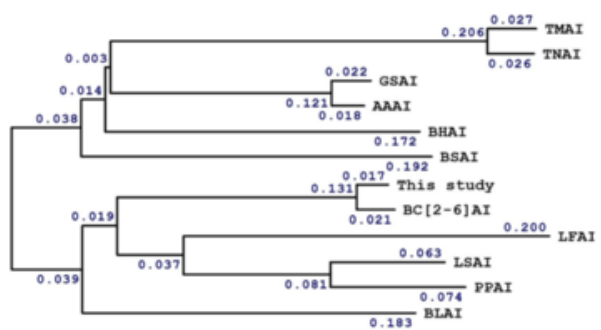

Fig. 2 (See legend on next page.) 
(See figure on previous page.)

Fig. 2 Multiple sequence alignment (a) and phylogenetic tree (b) of different bacterial Als using DNAMAN multiple alignment tool. The amino acid sequence of BCAl (This study) was aligned with other Al sequences from different bacterial sources including B. coagulans 2-6 (BC [2-6]Al, AEH54185.1), B. halodurans (BHAl, WP_010898034.1), B. licheniformis (BLAI, WP_011198012.1), B. subtilis (BSAl, WP_003237722), G. stearothermophilus (GSAl, ABY84698.1), L. fermentum CGMCC2921 (LFAl, 4LQL_A), L. sakei 23 K (LSAl, YP_396468.1), A. acidocaldarius (AAAl, AAY68209.1), P. pentosaceus PC-5 (PPAl, AEM17146.1), T. maritima (TMAl, AKE26215.1), T. neapolitana (TNAl, AAK18729.1). Identical and similar amino acid residues were respectively typed dark blue and purple. The putative catalytic residues which could also bind metal ions were marked with red boxes. Residues that can influence the optimal pH of Als were marked with blue box. The phylogenetic tree was generated using Neighbor-Joining method on the basis of the alignment above. The numbers in diagram b showed the lengths of branches that represented evolutionary relationships

activity. When incubated at $70{ }^{\circ} \mathrm{C}$ or higher temperatures, the enzymatic activity declined very quickly by more than $80 \%$ during the first $30 \mathrm{~min}$. Some reports showed that adding $\mathrm{Mn}^{2+}$ could enhance the thermostability of EDTA-treated AIs [8, 9]. But in this study, a low concentration of $\mathrm{Mn}^{2+}$ did not make the same enhancement effect on the raw purified BCAI. As shown in Fig. 5b, after incubation with $0.5 \mathrm{mM} \mathrm{Mn}^{2+}$ at temperatures between 60 and $90{ }^{\circ} \mathrm{C}$ for $2 \mathrm{~h}$, no positive changes appeared on the residual activities of the enzyme.

From the two perspectives of enzyme activity and thermostability, it seemed that external $\mathrm{Mn}^{2+}$ was not essential for the raw purified BCAI. Since a low amount of metallic ions can increase the purity and safety of products, BCAI will show its unique value in food-grade Dtagatose production.

Kinetic parameters of BCAI and molecular docking studies Kinetic constants of BCAI were measured by following the rules of Lineweaver-Burck plots (Table 2). The catalytic efficiencies $\left(k_{\text {cat }} / K_{\mathrm{m}}\right)$ of BCAI were $8.7 \mathrm{mM}^{-1} \mathrm{~min}^{-1}$ and $1.0 \mathrm{mM}^{-1} \mathrm{~min}^{-1}$ for L-arabinose and D-galactose respectively. According to the ratio (8.7: 1) between the $k_{\text {cat }} / \mathrm{Km}$ for L-arabinose and $\mathrm{D}$-galactose, L-arabinose was obviously a more favorable substrate than Dgalactose for BCAI. On the other hand, the $k_{\text {cat }} / K \mathrm{~m}$ for D-galactose of BCAI was noticeable because many other AIs from Bacillus strains had not been reported to show any catalytic efficiency for D-galactose [5, 13, 14].

Molecular modelling and docking techniques were used for gaining a deeper understanding of the substrate specificity. In previous studies, the monomers of $B$.

Table 1 Purification of BCAl expressed in recombinant E. coli

\begin{tabular}{|c|c|c|c|c|c|}
\hline $\begin{array}{l}\text { Purification } \\
\text { step }\end{array}$ & Protein(mg) & $\begin{array}{l}\text { Total } \\
\text { activity(U) }\end{array}$ & $\begin{array}{l}\text { Specific } \\
\text { activity }\left(\cup \mathrm{mg}^{-1}\right)\end{array}$ & Yield(\%) & $\begin{array}{l}\text { Purification } \\
\text { fold }\end{array}$ \\
\hline $\begin{array}{l}\text { Crude } \\
\text { extract }\end{array}$ & 39.4 & 89.9 & 2.3 & 100 & 1 \\
\hline $\begin{array}{l}\text { Heat } \\
\text { treatment }\end{array}$ & 15.7 & 78.4 & 5.0 & 87.2 & 2.2 \\
\hline $\begin{array}{l}\text { HisTrap } \\
\text { HP } 5 \mathrm{~mL} \\
\text { column }\end{array}$ & 2.3 & 18.3 & 8.0 & 20.3 & 3.5 \\
\hline
\end{tabular}

Then enzyme activity was measured using L-arabinose as a substrate licheniformis AI (BLAI) and P. pentosaceus PC-5 AI (PPAI) had been comparatively modeled by using the crystal structure of E. coli AI as a template [23, 24]. However, the crystallographic analysis on L. fermentum CGMCC2921 AI (LFAI) and E. coli AI (ECAI) indicated that they were hexamers $[25,26]$. Native-PAGE showed that the total molecular mass of BCAI was around $300 \mathrm{kDa}$, which meant that BCAI was also a hexamer (expected size: $320 \mathrm{kDa}$, Additional file 1: Figure S2). It could be assumed that substrate catalyses of these enzymes might be affected by subunit interactions. Therefore, monomer models were not accurate enough when protein subunit interactions were considered. In this study, half of the BCAI structure (a trimer, Additional file 2) was constructed on the base of LFAI (PDB ID: 4LQL, identity: $59.5 \%$ ) and ECAI (PDB ID: 4F2D, identity: $44.0 \%$ ) crystal structures. The present choice represents a compromise for achieving better conformations of the active sites and reducing computation size as well (Fig. 6a). The superimposition of the obtained BCAI structure with 4LQL and 4F2D ensured the conservation of the putative catalytic amino acids (E306, E331, H348 and H447) (Fig. 6b). The structure energy was sufficiently minimized through a 1000-step Conjugate Gradient Descent until the RMS Gradient reached 0.1.

Although molecular docking studies had been implemented on BLAI before, the result was not very representative because BLAI did not possess any D-galactose activity in experiments. Most AIs such as BCAI were able to catalyze L-arabinose and D-galactose simultaneously. As shown in Fig. 6c, two hydrogen bonds (2.15 $\AA, 2.34 \AA)$ existed between the $\mathrm{C} 2$ hydroxyl group of $\mathrm{L}$-arabinose and the oxygens of E306. One hydrogen bond (1.96 $\AA$ ) was found between the $C 1$ hydroxyl group and the oxygen of E331. According to the presumed catalytic mechanism of $E$. coli AI and B. licheniformis AI [26, 27], L-arabinose was firstly transformed to an enediol intermediate and then L-ribulose was formed. During the first step, protons were transferred through $\mathrm{C} 1$ and $\mathrm{C} 2$ of the substrate with the assistances of E306 and E331. The docking result here confirmed that E306 and E331 of BCAI played important roles of targeting the $\mathrm{C} 2$ and C1 hydroxyl groups of L-arabinose. The hydrogen bond 

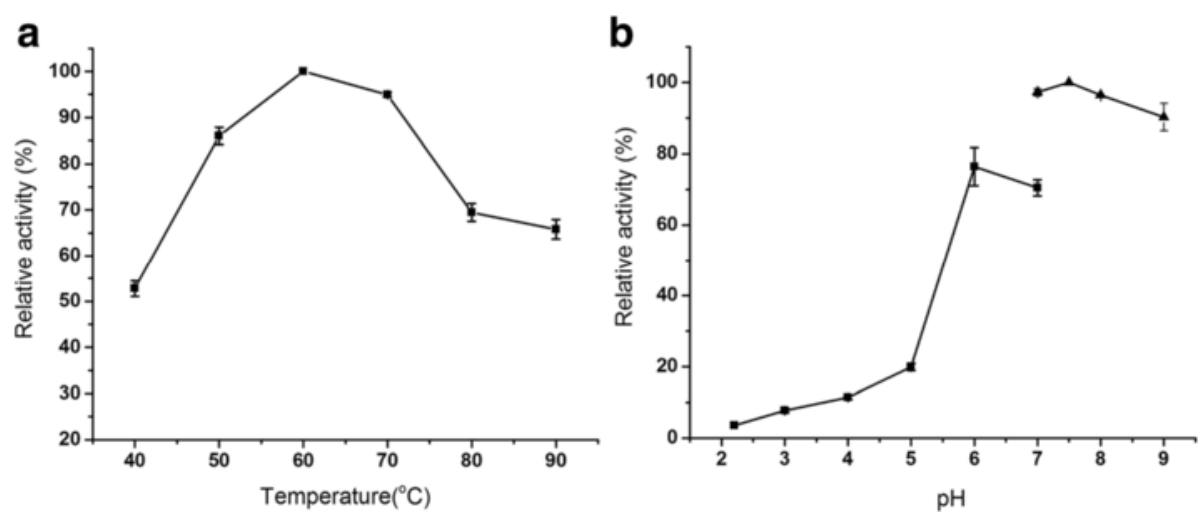

Fig. 3 Effects of temperature (a) and $\mathrm{pH}(\mathbf{b})$ on BCAl activity. Effect of temperature was determined at $\mathrm{pH} 7.5$ and effect of pH was measured at $60^{\circ} \mathrm{C}$. L-arabinose was used as the substrate. The activities at optimal temperature, $\mathrm{pH}$ were defined as $100 \%$

interactions between L-arabinose and the residues were sufficiently strong. By contrast, the interactions for Dgalactose were weaker. Among the two hydrogen bonds $(2.35 \AA$, $1.94 \AA)$ found in Fig. 6d, only the bond between the C3 hydroxyl group of D-galactose and E306 could promote the reaction according to the putative mechanism exposed above. E331 residue did not orientate the $\mathrm{C} 1$ hydroxyl group of $\mathrm{D}$-galactose correctly, which would cause difficulties on proton transfer and slowed formation of enediol intermediate. This could be an explanation for why the formation of D-tagatose was always slower than that of L-ribulose in most AI catalyses.

Meanwhile, the C-DOCKER energies for the docking poses of L-arabinose and D-galactose were $-9.39 \mathrm{kcal} /$ $\mathrm{mol}$ and $-7.07 \mathrm{kcal} / \mathrm{mol}$ respectively. A lower value indicates a more favorable binding, thus further confirming that $\mathrm{D}$-galactose is poorer fit in the active site pocket of BCAI than $\mathrm{L}$-arabinose.
Conversion of D-galactose to D-tagatose by using whole cells of recombinant $E$. coli

Since BCAI could isomerize D-galactose to D-tagatose, the feasibility of D-tagatose production was further studied. It was complicated to use purified enzyme as biocatalyst in industry. Instead, whole cells of recombinant $E$. coli was constructed and selected as a suitable biocatalyst for D-tagatose production.

To increase the efficiency of D-tagatose production, the biocatalytic conditions were optimized. The effect of cell concentration on D-tagatose production was firstly investigated. As shown in Fig. 7a, the highest conversion rate was obtained at $4.8 \mathrm{~g} \mathrm{DCW} \mathrm{L^{-1 }}$. Then, the effect of reaction temperature was evaluated within a temperature range from $40{ }^{\circ} \mathrm{C}$ to $80{ }^{\circ} \mathrm{C}$. Figure $7 \mathrm{~b}$ showed that the conversion rate reached a maximum $(40.8 \%)$ at $60{ }^{\circ} \mathrm{C}$. It was consistent with the optimum temperature of purified BCAI. Although E. coli cells suffer from viability loss and cellular structure
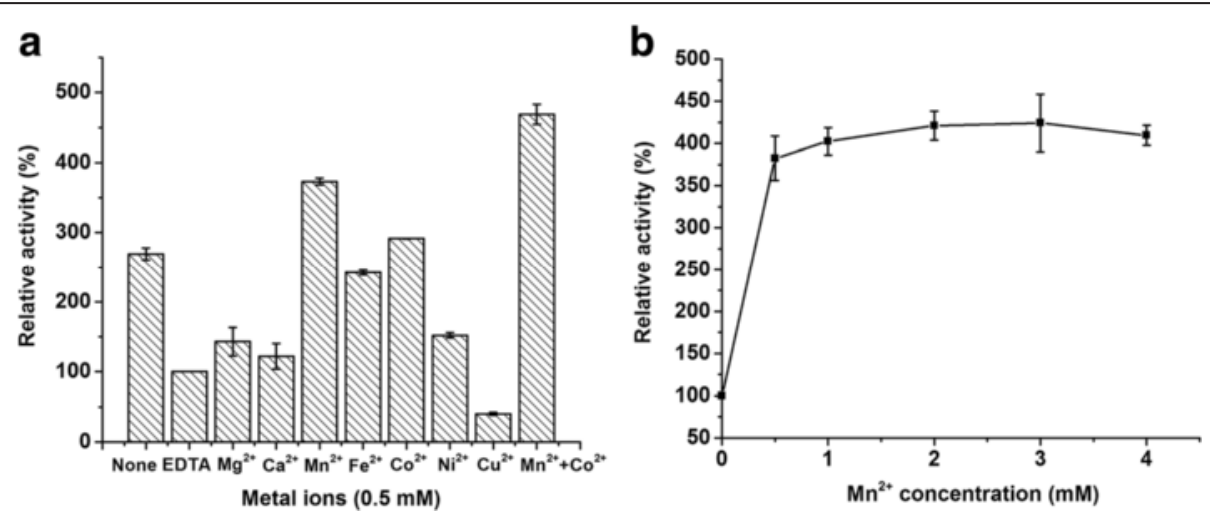

Fig. 4 Effects of various divalent metal ions at $0.5 \mathrm{mM}(\mathbf{a})$ and $\mathrm{Mn}^{2+}$ concentration (b) on BCAl activity. Enzyme assay was carried out at $60{ }^{\circ} \mathrm{C}$ and $\mathrm{pH}$ 7.5. None: purified BCAI without EDTA treatment; EDTA: purified BCAl treated by EDTA; The EDTA treated enzyme was used when determining of the effects of metal ions and $\mathrm{Mn}^{2+}$ concentration. $\mathrm{Mn}^{2+}+\mathrm{Co}^{2+}$ : the mixture of $0.5 \mathrm{mM} \mathrm{Mn}^{2+}$ and $0.5 \mathrm{mM} \mathrm{Co}^{2+}$ 

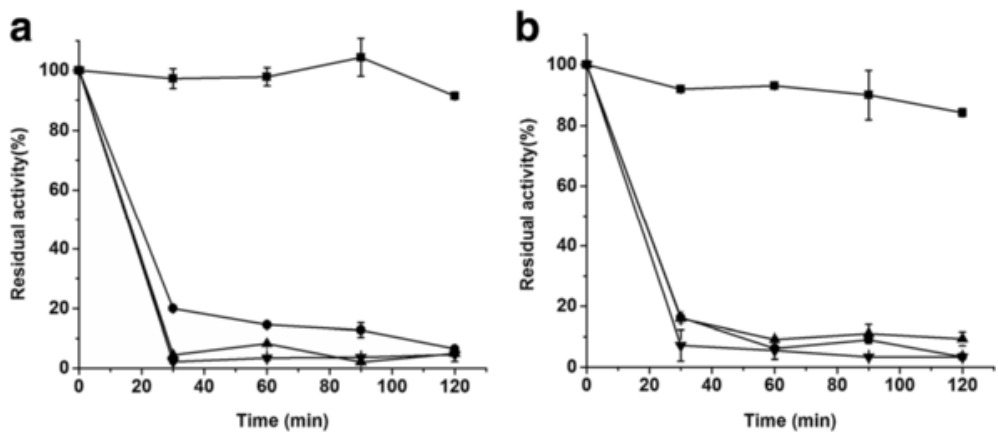

Fig. 5 Thermal profiles of BCAl without addition of metallic ions (a) and in the presence of $0.5 \mathrm{mM} \mathrm{Mn}^{2+}(\mathbf{b})$. The residual activities were determined at $60{ }^{\circ} \mathrm{C}(\mathbf{\bullet}), 70^{\circ} \mathrm{C}(\bullet), 80^{\circ} \mathrm{C}(\mathbf{\Delta})$ and $90^{\circ} \mathrm{C}(\mathbf{\nabla})$. The activity of a standard reaction at $60^{\circ} \mathrm{C}$ and 0 min was defined as $100 \%$

transition when the temperature is higher than $55{ }^{\circ} \mathrm{C}$ [21], these serious damages to $E$. coli cells did not suppresses the transportation of $\mathrm{D}$-galactose and $\mathrm{D}$ tagatose at $60{ }^{\circ} \mathrm{C}$. The effect of substrate concentration was tested in the range from $50 \mathrm{~g} \mathrm{~L}^{-1}$ to $250 \mathrm{~g} \mathrm{~L}^{-1} \mathrm{D}$ galactose $\left(4.8 \mathrm{~g} \mathrm{~L}^{-1}\right.$ cells and $\left.60^{\circ} \mathrm{C}\right)$. With the increase of $\mathrm{D}$-galactose concentration, the amount of D-tagatose kept rising without obvious substrate inhibition, whereas the conversion rate decreased from 31.4 to $17.0 \%$ (Fig. 7c). In order to achieve a higher yield of Dtagatose, $250 \mathrm{~g} \mathrm{~L}^{-1}$ galactose was firstly selected for the following experiment. Meanwhile, $150 \mathrm{~g} \mathrm{~L} \mathrm{~L}^{-1} \mathrm{D}$ galactose was contained, because a relatively higher conversion rate was also expected.

Based on the above experiments, the time course of tagatose production at $150 \mathrm{~g} \mathrm{~L}^{-1}$ and $250 \mathrm{~g} \mathrm{~L}^{-1}$ galactose were performed under the optimal conditions. After $32 \mathrm{~h}$ biotransformation, the concentrations of $\mathrm{D}$ tagatose were $48.1 \mathrm{~g} \mathrm{~L}^{-1}$ and $55.5 \mathrm{~g} \mathrm{~L}^{-1}$ respectively (Fig. 7 d). The conversion rates were 32.1 and $22.2 \%$ respectively. During the next $16 \mathrm{~h}$, the conversion rate for $250 \mathrm{~g} \mathrm{~L}^{-1} \mathrm{D}$-galactose rose up a little to $27.2 \%$. The achieved conversion rates were attractive for industrial
D-tagatose production. Although immobilized AIs from G. stearothermophilus, T. mathranii and T. neapolitana [28-30] had been used to produce D-tagatose before, the process in this study was easier to operate and due to the enzyme purification and immobilization steps were eliminated. It was a one-pot bioconversion process and introductions of high cell density cultivation and continuous reactors could hopefully improve its feasibility in the future.

\section{Conclusions}

In this study, an AI from B. coagulans NL01 was comprehensively studied. It showed a broad adaptability to moderate high temperatures. Its original dependency on added metallic ions such as $\mathrm{Mn}^{2+}$ was considerably low. Besides, molecular modelling of BCAI trimer combined with docking studies was used to understand its substrate specificity more deeply. Finally, a simple bioconversion system was established using whole cells of recombinant E. coli harboring BCAI as the biocatalyst. Attractive D-galactose conversion rates and D-tagatose productions were obtained.

Table $\mathbf{2}$ Kinetic parameters of Als

\begin{tabular}{|c|c|c|c|c|c|c|c|}
\hline \multirow[t]{2}{*}{ Source } & \multicolumn{3}{|l|}{ L-arabinose } & \multicolumn{3}{|l|}{ D-galactose } & \\
\hline & $\overline{V_{\max }\left(U \mathrm{mg}^{-1}\right)}$ & $K_{\mathrm{m}}(\mathrm{mM})$ & $k_{\text {cat }} / K_{\mathrm{m}}\left(\mathrm{min}^{-1} \mathrm{mM}^{-1}\right)$ & $V_{\max }\left(U \mathrm{mg}^{-1}\right)$ & $K_{\mathrm{m}}(\mathrm{mM})$ & $k_{\text {cat }} / K_{\mathrm{m}}\left(\mathrm{min}^{-1} \mathrm{mM}^{-1}\right)$ & \\
\hline B. coagulans NL01 & 43.7 & 269.8 & 8.7 & 6.8 & 355.1 & 1.0 & This study \\
\hline B. halodurans & 33.1 & 36 & 51 & 1.3 & 167 & 0.4 & [13] \\
\hline B. licheniformis & NR & 369 & 34 & NR & NR & NR & {$[15]$} \\
\hline B. substilis & NR & 120 & 121 & ND & ND & ND & {$[12]$} \\
\hline G. thermodenitrificans & 86 & 142 & 48 & NR & NR & 0.5 & {$[22]$} \\
\hline P. pentosaceus PC-5 & ND & ND & ND & 7.8 & 66 & 2.9 & [24] \\
\hline A. flavithermus & NR & 78.5 & 0.7 & NR & 25.2 & 5.2 & [11] \\
\hline T. neapolitana & 119 & 116 & 58.1 & 14.3 & 250 & 3.2 & {$[36]$} \\
\hline
\end{tabular}

Kinetic parameters of BCAl were determined by using 12.5 to $700 \mathrm{mM}$ substrate (L-arabinose or D-galactose) at standard enzyme assay conditions $\left(60{ }^{\circ} \mathrm{C}\right.$, pH 7.5 and $20 \mathrm{~min}$ ) 


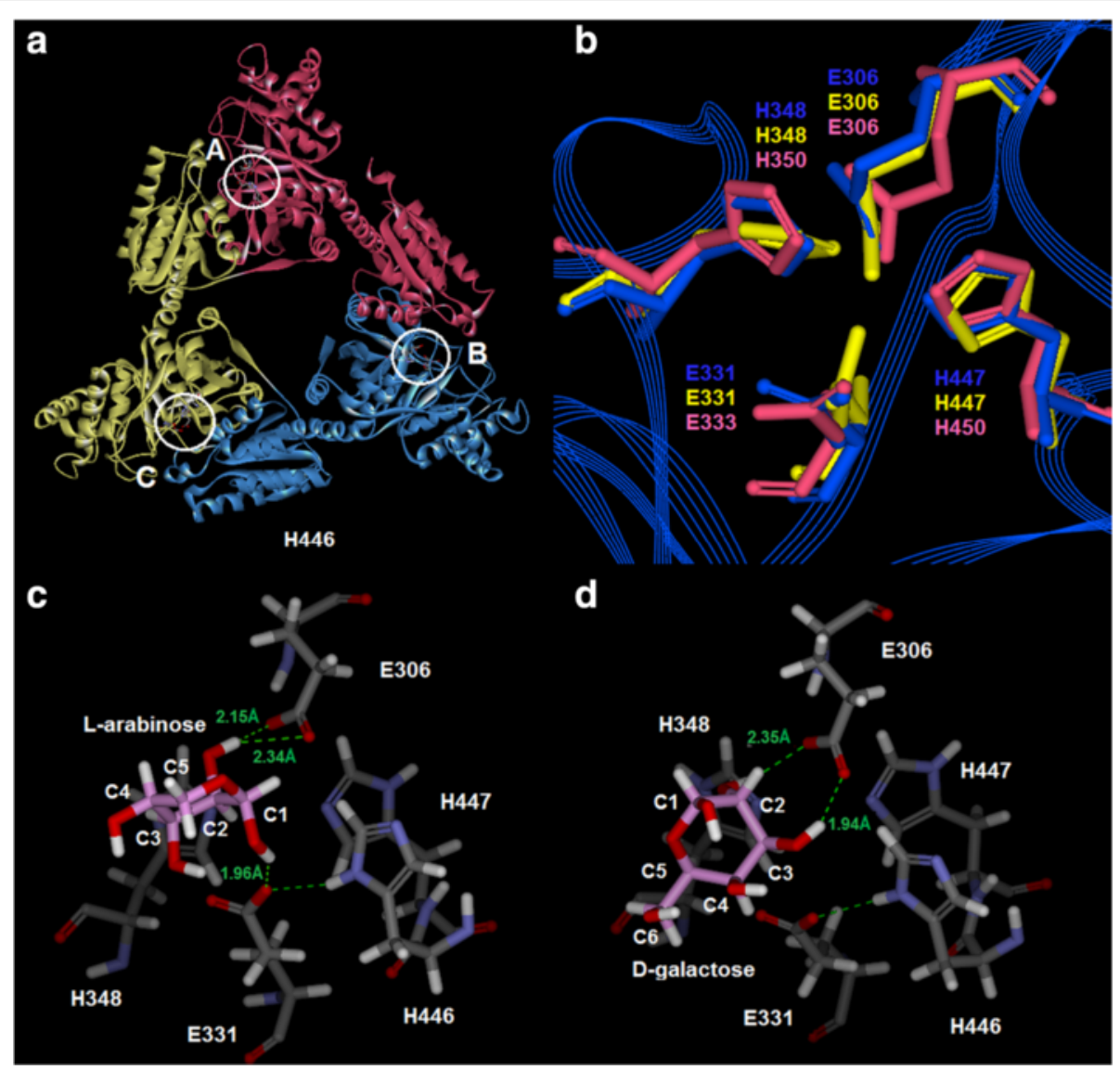

Fig. 6 Model of B. coagulans NL01 Al trimer (a). The locations of the three substrate active sites $(A, B, C)$ are close to the interface of two identical protein subunits. The model was constructed with the MODELLER module of Discovery Studio 4.0 package. Superimposition of the putative catalytic residues of BCAl (blue), L. fermentum CGMCC2921 Al (yellow, PDB ID: 4LQL) and E. coli Al (pink, PDB ID: 4F2D) (b). The complexes of BCAI active sites with $\mathrm{L}$-arabinose $(\mathbf{c})$ and D-galactose $(\mathbf{d})$. The intermolecular $\mathrm{H}$ bonds are represented by green dotted lines. L-arabinose, D-galactose molecules and amino acid residues are displayed in stick form and colored according to elemental types

\section{Methods}

\section{Strains, plasmids and reagents}

B. coagulans NL01 was stored in our lab and preserved at $-80{ }^{\circ} \mathrm{C}$ [31]. E. coli BL21 (DE3) was used as the expression host. Plasmid pEASY-Blunt (TransGen Biotech, China) and pETDuet-1 (Novagen) were used for gene cloning and gene expression respectively. FastPfu DNA polymerase was purchased from TransGen Biotech (China). HisTrap HP $5 \mathrm{~mL}$ column was from GE Health Life Science (USA). D-galactose, D-tagatose and L-arabinose were acquired from TCI (Japan) and L-ribulose was acquired from Carbosynth (United Kingdom).

\section{Construction of recombinant $E$. coli}

The B. coagulans L01 strain was cultured in LB medium for $12 \mathrm{~h}$. Its genomic DNA was extracted by using TIANamp Bacteria DNA Kit (TIANGEN, Beijing) and then was used as the template DNA of PCR amplication. The primers used for cloning the araA gene were 5' -CGCGGATCCGATGTTGAAAATAAAAGA3' (forward primer) and 5'-CCGGAATTCTGTTAAAGAAGTGCATC-3' (reverse primer). The underlined sequences represent restriction sites $B a m \mathrm{H}$ I and EcoR I respectively. The PCR product was ligated with pEASY-Blunt cloning vector. The resulting recombinant plasmid was sequenced by BGI Tech. (Shanghai, China). Then, both the recombinant cloning plasmid and the expression vector pETDuet-1 were digested with $B a m \mathrm{H} \mathrm{I}$ and EcoR I, and the $\operatorname{araA}$ gene was cloned into the multiple cloning sites of pETDuet- 1 to generate the recombinant expression plasmid, pETDuet-araA. Finally, the plasmid was transformed into E. coli BL21 (DE3) for expression.

Overexpression of the araA gene and enzyme purification The E. coli BL21 (DE3) harboring pETDuet-araA gene was grown in LB medium with shaking at $37{ }^{\circ} \mathrm{C}$ until $\mathrm{OD}_{600}$ reaches 0.6-0.8. IPTG was added into the medium with a final concentration of $0.5 \mathrm{mM}$ for the 

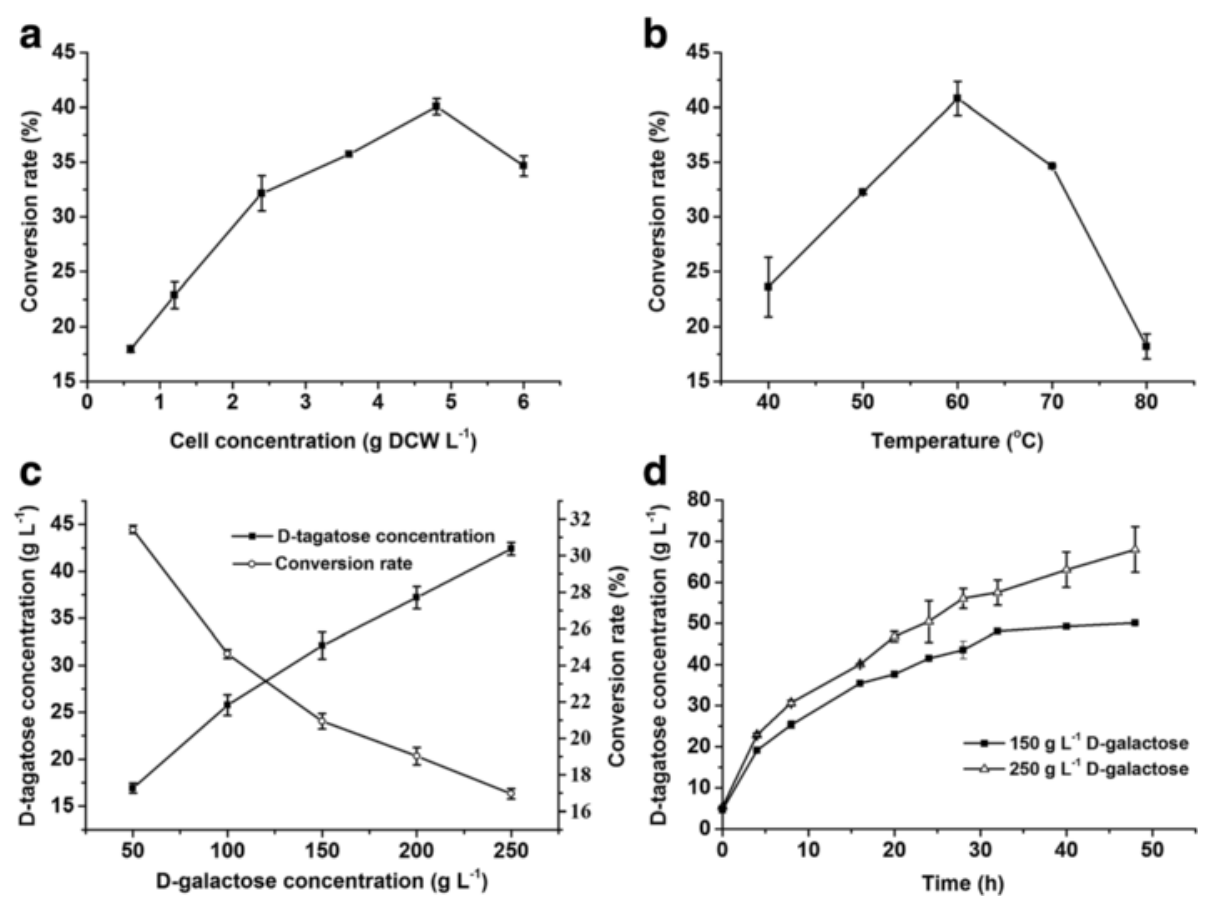

Fig. 7 Effect of cell concentration on the conversion rate of D-tagatose (a). Reaction conditions: $18 \mathrm{~g} \mathrm{~L}^{-1} \mathrm{D}$-galactose, $50 \mathrm{mM} \mathrm{Tris-HCl,} 60^{\circ} \mathrm{C}, 15 \mathrm{~h}$. Effect of temperature on the conversion rate of D-tagatose (b). Reaction conditions: $18 \mathrm{~g} \mathrm{~L}^{-1}$ D-galactose, $50 \mathrm{mM} \mathrm{Tris-HCl,} 4.8 \mathrm{~g} \mathrm{~L}^{-1} \mathrm{E}$. coli cells, $15 \mathrm{~h}$. Effect of D-galactose concentration on the conversion rate of D-tagatose (c). Symbols: ( $\mathbf{a})$ the D-tagatose concentration; ( 0 ) the conversion rate of D-tagatose. Reaction conditions: $4.8 \mathrm{~g} \mathrm{~L}^{-1} \mathrm{E}$. coli cells, $50 \mathrm{mM}$ Tris- $\mathrm{HCl}, 60^{\circ} \mathrm{C}, 15 \mathrm{~h}$. Time course of D-tagatose conversion (d). Symbols: (- $)$

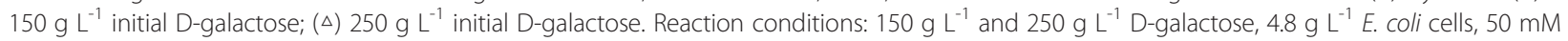
Tris- $\mathrm{HCl}, 60^{\circ} \mathrm{C}, 48 \mathrm{~h}$

recombinant protein expression. After incubation at $25^{\circ}$ $\mathrm{C}$ and $200 \mathrm{rpm}$ for $8 \mathrm{~h}$, cells were harvested by centrifugation and resuspended in phosphate buffer solution (PBS, $50 \mathrm{mM}, \mathrm{pH}$ 7.4). Cell disruption was carried out by sonication and the obtained solution was centrifugated at $10,000 \times \mathrm{g}$ for $15 \mathrm{~min}$ at $4{ }^{\circ} \mathrm{C}$ to remove insoluble cell debris. The supernatant was used as crude cell extract. For the following purification, the crude extract was heated at $60{ }^{\circ} \mathrm{C}$ in order to remove host proteins. Then it was filtered by a $0.22-\mu \mathrm{m}$ filtering membrane and loaded on a HisTrap HP $5 \mathrm{~mL}$ column and equilibrated with binding buffer ( $20 \mathrm{mM}$ sodium phosphate, $500 \mathrm{mM}$ sodium chloride, and $20 \mathrm{mM}$ imidazole, $\mathrm{pH}$ 7.4). The target protein (BCAI) was eluted with $60 \%$ binding buffer and $40 \%$ elution buffer $(20 \mathrm{mM}$ sodium phosphate, $500 \mathrm{mM}$ sodium chloride, $500 \mathrm{mM}$ imidazole, pH 7.4). Purity of the protein was assessed by $11.25 \%$ SDS-PAGE. Estimation of molecular mass of multimeric protein was carried out by using 4-16\% Native-PAGE. Gels were visualized by Coomassie Blue R250 staining. The expected band size of BCAI monomer and hexamer was predicted by Compute $\mathrm{pI} / \mathrm{Mw}$ tool (http://web.expasy.org/compute_pi/). Purified BCAI was stored at $4{ }^{\circ} \mathrm{C}$ for biochemical property studies.

\section{Enzyme assay and protein determination}

The activity of BCAI was measured by determining the amount of formed keto sugar (L-ribulose or D-tagatose). Under standard conditions, $1 \mathrm{~mL}$ reaction mixture contained $100 \mathrm{mM} \mathrm{L}$-arabinose or D-galactose, $50 \mathrm{mM}$ Tris- $\mathrm{HCl}$ buffer (pH 7.5), $1 \mathrm{mM} \mathrm{MnCl} \mathrm{M}_{2}$ and $100 \mu \mathrm{L}$ of enzyme solution at a suitable concentration. The reaction mixture was incubated at $60^{\circ} \mathrm{C}$ for $20 \mathrm{~min}$. Samples were cooled on ice for stopping the reaction. The amount of L-ribulose or D-tagatose was determined by cysteine-carbazole-sulfuric-acid method and the absorbance at $560 \mathrm{~nm}$ [32]. One unit of AI acitivity was defined as the amount of enzyme producing $1 \mu \mathrm{mol}$ keto sugar per min under the conditions above. The protein concentration was determined by the Bradford (Sigma) method using bovine serum albumin for calibration.

\section{Effects of temperature, $\mathrm{pH}$ and metallic ion on purified BCAI}

The effect of temperature on activity of purified BCAI was determined by testing the activities at temperatures from $40{ }^{\circ} \mathrm{C}$ to $90{ }^{\circ} \mathrm{C}$ at $\mathrm{pH} 7.5$. The effect of $\mathrm{pH}$ was determined by testing the activities at $\mathrm{pH} 2$ to 9 and the optimal temperature obtained above. 
Two buffer systems, disodium hydrogen phosphatecitric acid (50 mM, pH 2.2 to 7.0$)$ and Tris- $\mathrm{HCl}$ (50 mM, pH 7.0 to 9.0) were used to get desired $\mathrm{pH}$ ranges.

To investigate the effect of metal ions on BCAI activity, purified BCAI was dialyzed against $50 \mathrm{mM}$ Tris- $\mathrm{HCl}$ buffer ( $\mathrm{pH}$ 7.5) containing $10 \mathrm{mM}$ EDTA at $25{ }^{\circ} \mathrm{C}$ for $3 \mathrm{~h}$. Then, the buffer was changed to $50 \mathrm{mM}$ Tris- $\mathrm{HCl}$ $(\mathrm{pH} 7.5)$ for another dialysis of $36 \mathrm{~h}$. Metallic ions were added into reaction mixture containing EDTA-treated BCAI at a final concentration of $0.5 \mathrm{mM}$ (or 0.5 to $4 \mathrm{mM}$ when studying effect of $\mathrm{Mn}^{2+}$ concentration). Enzyme assay was carried out at the standard condition without adding other metallic ions.

To investigate the thermostability, the raw purified BCAI was divided into two groups. One is incubated without $\mathrm{Mn}^{2+}$ and the other is incubated in presence of $0.5 \mathrm{mM} \mathrm{Mn}{ }^{2+}$. The incubations are at 60 to $90{ }^{\circ} \mathrm{C}$ and $\mathrm{pH} 7.5$ for $120 \mathrm{~min}$. The enzyme activity was measured under the standard condition without addition of $\mathrm{Mn}^{2+}$.

\section{Determination of kinetic parameters}

Kinetic parameters were determined using a $50 \mathrm{mM}$ Tris-HCl buffer (pH 7.5), and 12.5 to $700 \mathrm{mM}$ substrate (L-arabinose or D-galactose) and incubation for $20 \mathrm{~min}$ at $60{ }^{\circ} \mathrm{C}$. The reaction was stopped by cooling on ice and the amount of L-ribulose or D-tagatose was determined by cysteine-carbazole-sulfuric-acid method.

\section{Molecular modelling and docking studies}

The template structures for comparative modelling were searched from RCSB PDB database (http://www.rcsb.org/). The structure of BCAI trimer was constructed with the MODELLER program and validated by the Profiles-3D tool in Discovery Studio 4.0 package (DS 4.0, BIOVIA, San Diego, CA). Then the protein structure typed with CHARMm [33] force field and the substrate structures typed with MMFF94 force field [34] were subjected to energy minimizations using Conjugate Gradient Descent algorithm. Then, the substrate molecules were docked into the binding pocket of BCAI by using CDOCKER module [35]. The docking poses with the lowest interaction energy were selected for the analysis of orientation and binding interaction.

\section{Optimization of D-tagatose transformation conditions}

\section{using recombinant $E$. coli cells containing BCAI}

$10 \mathrm{~mL}$ reaction mixtures were prepared in a $50 \mathrm{~mL}$ centrifuge tube containing $50 \mathrm{mM}$ Tris- $\mathrm{HCl}$ buffer ( $\mathrm{pH}$ 7.5). The optimal cell concentration was determined by adding 0.6 to $6 \mathrm{~g} \mathrm{~L}^{-1}$ recombinant $E$. coli cells to the reaction mixtures and carrying out an incubation at $60{ }^{\circ} \mathrm{C}$ for $15 \mathrm{~h}$. The optimal reaction temperature was determined by incubating the reaction mixtures at $40{ }^{\circ} \mathrm{C}$ to $80{ }^{\circ} \mathrm{C}$ with the optimal concentration of $E$. coli cells. Then, a gradient of D-galactose concentrations (50 to $250 \mathrm{~g} \mathrm{~L}^{-1}$ ) were set for investigating their effect on the conversion rate. The time courses were tested with the selected D-galactose concentrations at the optimal conditions. Samples were taken periodically and analyzed by a high-performance liquid chromatography (HPLC) system (Agilent 1200 series, USA).

\section{Analytical methods}

The amount of D-galactose and D-tagatose was measured by a HPLC equipped with a Waters Sugar-pak1 column $(6.5 \times 300 \mathrm{~mm})$ and a refractive index detector (SHIMADZU). Deionized water was used as mobile phase at a flow rate of $0.4 \mathrm{~mL} \min ^{-1}$ and a column temperature of $80{ }^{\circ} \mathrm{C}$ [24].

\section{Additional files}

Additional file 1: Figure S1. SDS-PAGE analysis of the proteins from different purification steps. Figure S2. Native-PAGE analysis of purified BCAl. (DOCX 646 kb)

Additional file 2: Sequence of BCAl trimer model. (DOCX $19 \mathrm{~kb}$ )

\section{Abbreviations}

Al, L-arabinose isomerase; BCAl, Bacillus coagulans NL01 Al; DCW, dry cell weight; EDTA, ethylenediaminetetraacetic acid; HPLC, high-performance liquid chromatography; IPTG, isopropyl $\beta$-D-thiogalactopyranoside; $P C R$, polymerase chain reaction

\section{Acknowledgements}

We thank for Dr. Bingfang He from Nanjing Tech University for offering Discovery Studio Package 4.0 software.

\section{Funding \\ The research project was financially supported by the National Natural Science Foundation of China $(51561145015,31300487)$, the Natural Science Foundation of Jiangsu Province of China (BK20130970) and the Priority Academic Program Development of Jiangsu Higher Education Institutions (PAPD).}

\section{Availability of data and materials}

The dataset of sequences supporting the conclusions of this article is available in the GenBank (http://www.ncbi.nlm.nih.gov/genbank/). Accession number of B. coagulans NL01 araA gene: KX356659. Protein ID of B. coagulans NL01 L-arabinose isomerase: ANJ21429.

\section{Authors' contributions}

WM participated in the design of the experiments, data analysis and writing the manuscript. LW carried out the experiments of whole cell catalysis; ZY participate in the experiments of molecular biology. ZZ participated in data analysis and modifying the manuscript; JO coordinated the whole project and completed the manuscript. All authors read and proved the final manuscript.

\section{Competing interests}

The authors declare that they have no competing interests.

Consent for publication

Not applicable.

Ethics approval and consent to participate Not applicable. 


\section{Author details}

${ }^{1}$ College of Chemical Engineering, Nanjing Forestry University, Nanjing 210037, People's Republic of China. ${ }^{2}$ College of Forestry, Nanjing Forestry University, Nanjing 210037, People's Republic of China. ${ }^{3}$ Key Laboratory of Forest Genetics \& Biotechnology of the Ministry of Education, Nanjing, People's Republic of China.

Received: 22 January 2016 Accepted: 21 June 2016

Published online: 30 June 2016

\section{References}

1. Donner T, Wilber JF, Ostrowski D. D-tagatose, a novel hexose: acute effects on carbohydrate tolerance in subjects with and without type 2 diabetes. Diabetes Obes Metab. 1999;1(5):285-91.

2. Kim P. Current studies on biological tagatose production using L-arabinose isomerase: a review and future perspective. Appl Microbiol Biot. 2004;65:243-9.

3. Salonen N, Salonen K, Leisola M, Nyyssola A. D-Tagatose production in the presence of borate by resting Lactococcus lactis cells harboring Bifidobacterium longum L-arabinose isomerase. Bioproc Biosyst Eng. 2013; 36(4):489-97.

4. Heath $E$, Horecker B, Smyrniotis P, Takagi Y. Pentose fermentation by Lactobacillus plantarum II. L-arabinose isomerase. J Biol Chem. 1958;231(2):1031-7.

5. Xu Z, Li S, Feng X, Liang J, Xu H. L-Arabinose isomerase and its use for biotechnological production of rare sugars. Appl Microbiol Biot. 2014; 98(21):8869-78.

6. Cheetham P, Wootton A. Bioconversion of D-galactose into D-tagatose. Enzyme Microb Tech. 1993;15(2):105-8.

7. Boudebbouze S, Maguin E, Rhimi M. Bacterial L-arabinose isomerases: industrial application for D-tagatose production. Recent Pat DNA Gene Seq. 2011;5(3):194-201.

8. Rhimi M, Bejar S. Cloning, purification and biochemical characterization of metallic-ions independent and thermoactive $L$-arabinose isomerase from the Bacillus stearothermophilus US100 strain. Biochim Biophys Acta. 2006; 1760(2):191-9.

9. Lee DW, Jang HJ, Choe EA, Kim BC, Lee SJ, Kim SB, Hong YH, Pyun YR. Characterization of a thermostable L-arabinose (D-galactose) isomerase from the hyperthermophilic eubacterium Thermotoga maritima. Appl Environ Microb. 2004;70(3):1397-404.

10. Kim BC, Lee YH, Lee HS, Lee DW, Choe EA, Pyun YR. Cloning, expression and characterization of $L$-arabinose isomerase from Thermotoga neapolitana: bioconversion of D-galactose to D-tagatose using the enzyme. Fems Microbiol Lett. 2002;212(1):121-6.

11. Li Y, Zhu Y, Liu A, Sun Y. Identification and characterization of a novel I-arabinose isomerase from Anoxybacillus flavithermus useful in D-tagatose production. Extremophiles. 2011;15(3):441-50.

12. Kim JH, Prabhu P, Jeya M, Tiwari MK, Moon HJ, Singh RK, Lee JK. Characterization of an L-arabinose isomerase from Bacillus subtilis. Appl Microbiol Biotechnol. 2010;85(6):1839-47.

13. Lee DW, Choe EA, Kim SB, Eom SH, Hong YH, Lee SJ, Lee HS, Lee DY, Pyun YR. Distinct metal dependence for catalytic and structural functions in the L-arabinose isomerases from the mesophilic Bacillus halodurans and the thermophilic Geobacillus stearothermophilus. Arch Biochem Biophys. 2005; 434(2):333-43.

14. Zhou X, Wu JC. Heterologous expression and characterization of Bacillus coagulans I-arabinose isomerase. World J Microb Biot. 2012;28(5):2205-12.

15. Prabhu P, Tiwari MK, Jeya M, Gunasekaran P, Kim IW, Lee JK. Cloning and characterization of a novel $L$-arabinose isomerase from Bacillus licheniformis. Appl Microbiol Biot. 2008;81(2):283-90.

16. Cheng $L, M u W$, Jiang B. Thermostable L-arabinose isomerase from Bacillus stearothermophilus IAM 11001 for D-tagatose production: gene cloning, purification and characterisation. J Sci Food Agric. 2010;90(8):1327-33.

17. $X u$ Z, Qing Y, Li S, Feng $X, X u H$, Ouyang P. A novel L-arabinose isomerase from Lactobacillus fermentum CGMCC2921 for D-tagatose production: Gene cloning, purification and characterization. J Mol Catal B-Enzym. $2011 ; 70(1-2): 1-7$

18. Lee SJ, Lee SJ, Lee YJ, Kim SB, Kim SK, Lee DW. Homologous alkalophilic and acidophilic $\mathrm{L}$-arabinose isomerases reveal region-specific contributions to the $\mathrm{pH}$ dependence of activity and stability. Appl Environ Microbiol. 2012;78(24):8813-6.
19. Lee SJ, Lee DW, Choe EA, Hong YH, Kim SB, Kim BC, Pyun YR. Characterization of a thermoacidophilic L-arabinose isomerase from Alicyclobacillus acidocaldarius: role of Lys-269 in pH optimum. Appl Environ Microbiol. 2005;71(12):7888-96.

20. Xu Z, Li S, Feng X, Zhan Y, Xu H. Function of aspartic acid residues in optimum $\mathrm{pH}$ control of L-arabinose isomerase from Lactobacillus fermentum. Appl Microbiol Biot. 2013;98(9):3987-96.

21. Lee J, Kaletunc G. Evaluation of the Heat Inactivation of Escherichia coli and Lactobacillus plantarum by differential scanning calorimetry. Appl Environ Microb. 2002;68(11):5379-86.

22. Kim HJ, Oh DK. Purification and characterization of an L-arabinose isomerase from an isolated strain of Geobacillus thermodenitrificans producing D-tagatose. J Biotechnol. 2005;120(2):162-73.

23. Prabhu P, Jeya M, Lee JK. In silico studies on the substrate specificity of an L-arabinose isomerase from Bacillus licheniformis. Bioorg Med Chem Lett. 2010;20(15):4436-9.

24. Men Y, Zhu Y, Zhang L, Kang Z, Izumori K, Sun Y, Ma Y. Enzymatic conversion of D-galactose to D-tagatose: cloning, overexpression and characterization of L-arabinose isomerase from Pediococcus pentosaceus PC-5. Microbiol Res. 2014; 169(2-3):171-8.

25. Xu Z, Li S, Liang J, Feng X, Xu H. Protein purification, crystallization and preliminary $X$-ray diffraction analysis of $L$-arabinose isomerase from Lactobacillus fermentum CGMCC2921. Acta Crystallogr F. 2015;71(Pt 1):28-33.

26. Manjasetty BA, Chance MR. Crystal structure of Escherichia coli L-arabinose isomerase (ECAI), the putative target of biological tagatose production. J Mol Biol. 2006;360(2):297-309.

27. Prabhu P, Jeya M, Lee JK. Probing the molecular determinant for the catalytic efficiency of L-arabinose isomerase from Bacillus licheniformis. Appl Environ Microbiol. 2010;76(5):1653-60.

28. Liang M, Chen M, Liu X, Zhai Y, Liu XW, Zhang H, Xiao M, Wang P. Bioconversion of

D-galactose to D-tagatose: continuous packed bed reaction with an immobilized thermostable L-arabinose isomerase and efficient purification by selective microbial degradation. Appl Microbiol Biot. 2011;93(4):1469-74.

29. Kim HJ, Ryu SA, Kim P, Oh DK. A feasible enzymatic process for D-tagatose production by an immobilized thermostable L-arabinose isomerase in a packed-bed bioreactor. Biotechnol Prog. 2003;19(2):400-4.

30. Lim BC, Kim HJ, Oh DK. Tagatose production with $\mathrm{pH}$ control in a stirred tank reactor containing immobilized L-arabinose rom Thermotoga neapolitana. Appl Biochem Biotech. 2008;149(3):245-53.

31. Ouyang J, Cai C, Chen H, Jiang T, Zheng Z. Efficient non-sterilized fermentation of biomass-derived xylose to lactic acid by a thermotolerant Bacillus coagulans NL01. Appl Biochem Biotech. 2012;168(8):2387-97.

32. Dische $Z$, Borenfreund $E$. A new spectrophotometric method for the detection and determination of keto sugars and trioses. J Blol Chem. 1951; 192(2):583-7.

33. Brooks BR, Brooks 3rd CL, Mackerell Jr AD, Nilsson L, Petrella RJ, Roux B, Won Y, Archontis G, Bartels C, Boresch S, et al. CHARMM: the biomolecular simulation program. J Comput Chem. 2009;30(10):1545-614.

34. Halgren TA. Merck molecular force field. I. Basis, form, scope, parameterization, and performance of MMFF94. J Comput Chem. 1996;17(5-6):490-519.

35. Wu G, Robertson DH, Brooks CL, Vieth M. Detailed analysis of grid-based molecular docking: A case study of CDOCKER-a CHARMm-based MD docking algorithm. J Comput Chem. 2003;24(13):1549-62.

36. Hong YH, Lee DW, Lee SJ, Choe EA, Kim SB, Lee YH, Cheigh Cl, Pyun YR. Production of D-tagatose at high temperatures using immobilized Escherichia coli cells expressing L-arabinose isomerase from Thermotoga neapolitana. Biotechnol Lett. 2007;29(4):569-74. 